

ELS-JISH

ELS Journal on Interdisciplinary Studies on Humanities

Volume 3 Issue 4, 2020

ISSN (print) : 2621-0843

ISSN (online) : 2621-0835

Homepage : http://journal.unhas.ac.id/index.php/jish

\title{
Students' Perceptions of the Strategies Used by Teachers in Teaching Speaking in Desa Bahasa Sragen
}

\author{
Novita Indah Purwaningsih ${ }^{1}$, Agus Wijayanto ${ }^{2}$, Ngadiso ${ }^{3}$ \\ ${ }^{1}$ novitaindahpurwaningsih@gmail.com
}

\begin{abstract}
The objective of this study was to determine students' perceptions of the teaching strategies used by teachers to teach speaking in "Desa Bahasa Sragen". The subjects of this study were the six students of the "Desa Bahasa Sragen". There are six students who voluntarily agreed to be participants in this study. The instruments used to gather data was interviews. The case study is used in this research as a research method. The results showed that the students gave a positive perception of the strategies used by the teacher in teaching speaking in "Desa Bahasa Sragen". They stated that the strategies used by the teacher in teaching speaking in "Desa Bahasa Sragen" could help them practice speaking, making them feel the learning process fun. In addition, their positive perceptions are influenced by the new experiences they get while learning English, especially speaking in "Desa bahasa Sragen".
\end{abstract}

Keywords: Students' Perception, Strategies, Speaking, Desa Bahasa Sragen

How to cite: Purwaningsih, N. I., Wijayanto, A. \& Ngadiso. (2020). Students' Perceptions of the Strategies Used by Teachers in Teaching Speaking in Desa Bahasa Sragen. ELS Journal on Interdisciplinary Studies in Humanities, 3(4), 543-551. DOI:

https://doi.org/10.34050/elsjish.v3i4.11750

\section{Introduction}

The goal of this study is to find out the students' perception of the strategies used by the teacher to teach speaking. This topic is important because speaking is the most common and important means of providing communication among humans. Speaking English is important for interaction in airports, market, hospitals, schools, restaurants, train station, and shopping center. In Indonesia, English is considered as a foreign language so people inevitably have to use English as a medium of communication with foreigners in order to make it easier for the foreigners to communicate with Indonesians. However, in learning English speaking skills, there are difficulties that students must face: difficulty choosing the correct words, lack of confidence in speaking English, fear of making mistakes, and so on. In learning and teaching English, both teachers and students have several strategies to teach or improve students' speaking skills. According to Reiser and Dick (1996), the teacher can

\footnotetext{
${ }^{1,3}$ Sebelas Maret University, Indonesia

${ }^{2}$ Muhammadiyah University of Surakarta, Indonesia
} 
use and implement a variety of different strategies to achieve teaching and learning goals. Strategy itself makes students easier to achieve their ability, because in speaking, students not only master pronunciation or vocabulary but also know the strategies which are appropriate for them.

According to Cole (2008), the teacher's role is to plan and prepare an effective strategy to meet the needs of students whose goal is to communicate using the language being studied, which in this case is English. In the process of teaching speaking skills, students need a teacher who can help them achieve their desired goals, such as having good pronunciation and feeling more confident. According to Isjoni (2009) teachers have an important role in educating and influencing students so that they excel and have the abilities they need. Actually, in learning English, some teachers usually prefer to use group presentations on the grounds of helping students improve their speaking skills and self-confidence. According to Shimizu (2004), self-confidence is the most important factor that determines whether or not students are active to participate in oral activities in the classroom. In learning activities, teachers can use several strategies that are believed to help students develop their English. Even if students are not perfect in grammatical or lexical terms, in the process of using language for communication, students will be given input by the teacher so that they can improve their English. Some students not only implemented the strategy but also gave their opinion regarding the teacher's strategy. For example, when the teacher applies a group discussion strategy and class presentations, students can give their opinion about the strategy. Apart from that, there are reasons why researchers want to know about teachers' strategies in teaching speaking skills in English courses. Researchers believe that if there is confidence in speaking, communication will be well established. Unfortunately, most students lack confidence in speaking English (Hasria, Fathu, and Andjarwati 2018), even they feel reluctant to practice speaking with friends or use it in daily conversations because they are afraid of making mistakes and are afraid of being ridiculed by their friends (Junaidi, Hamuddin, Julita, Rahman, \& Derin, 2020). Therefore, a teacher must be able to create attractive strategies in teaching speaking skills. Strategies can help students practice their speaking skills so that they can be used both in teaching and learning processes and daily conversations.

There are several researchers who studied the strategies teachers use in teaching speaking. All these researchers studied speaking teaching strategies in formal schools, but none of them analyzed the speaking skills teaching strategies in the courses. Therefore, researchers are interested in analyzing students' perceptions of the strategies used by teachers in teaching speaking.

This research topic will be analyzed using the theory of perception. According to Robbins (1996) perception is a process where individuals organize and interpret information to provide something useful for their environment. In addition, Kotler (2000) defines perception as the process of how a person selects, arranges, and describes information input to create a meaningful complete conception. In addition, according to Ried in Nichols (2007), perception is the process of justifying belief in a certain object. In this process, people may provide arguments about what they see as the way they perceive 
things. In addition, this belief will make them accept things as they are. Walgito (2010) mentions three components of perception, namely cognitive, affective, and conative components.

\section{Method}

This research is a qualitative research with a case study method. According to Ary et al (2002), a case study is an in-depth study of a unit, such as an individual, a group, an organization, a program, and so on to arrive at a detailed description and understanding of something. In addition, Stake (1997) in Creswell (2003) states that researchers explore in depth a program, event, activity, process, or one or more individuals. The cases were time and activity constrained and the researcher gathered detailed information using various data collection procedures over a period of time. Researchers used a case study in this study to obtain detailed information about students' perceptions of the strategies used by the teachers in the Desa Bahasa Sragen. The participants of this research were all six students of the Desa Bahasa Sragen. The researcher chose to involve all students as participants because of their small number.

The data collection technique used was interviews. Researchers used this technique to collect clarifying data, verify what is on their mind about the problem being researched. This is a more open-minded technique because the researcher got information directly from the respondent. As Ary, et al. (2010) explained that interviews are used to collect data about the subject's opinions, beliefs, and feelings about the situation in his own words. In this study, researchers used a structured interview method. In this study, interviews were conducted to collect data in the form of information about students' perceptions of the strategies used by teachers in Desa Bahasa Sragen. In addition, researchers used a voice recorder during the interview.

There are several procedures that researcher used to analyze data; namely data collection, data reduction, data presentation and drawing conclusions. In collecting this data, researcher took data about students' perceptions of the strategies used by the teacher in teaching speaking using interviews with students. The next stage is data reduction. At this data reduction stage there is a life process in process and a life-out process. This means that the selected data is included in the required data and remains in the live data and the data that is not selected is included in the live data out. In this study, data reduction was in the form of a partial result of interviews with students of Desa Bahasa Sragen. Some information is required in data entry, but some of it is not needed. Therefore, the nonessential data was reduced by the researcher. The data display presents a simple data presentation process in the form of words, sentences, narratives, tables, and graphics so that the collected data can be understood by the researcher as a basis for drawing appropriate conclusions. In this study, the data display consisted of information about students' perceptions of the strategies used by the teacher in teaching speaking in Desa Bahasa Sragen. Drawing conclusions is the last stage in which the researcher summarizes the discussion to make conclusions from this research. This is the final procedure in analyzing the research data. After the data is displayed, conclusions are drawn. Here there are two kinds of drawing 
conclusions, namely temporary drawing conclusion and final drawing conclusion. Based on the presentation of the data, a temporary conclusion is then formulated. These temporary conclusions will continue to evolve in line with the discovery of new data and new insights, so that a solid conclusion will be obtained and is completely in accordance with the actual situation. And so on, this research activity takes place, that is, the continuous interaction between the three components of the analysis along with the collection of new data that is felt can produce complete data so that final conclusions can be formulated. If the temporary conclusion is valid and can answer the research problem, then the researcher can use it as a final conclusion. Meanwhile, if the temporary conclusion is not valid, the researcher has to repeat the process starting from displaying the data to find out whether the data displayed is in accordance with the formulation of the research problem or not.

\section{Findings}

\subsection{Students' perceptions of the strategies used by the teacher to teach speaking}

To determine students' perceptions of the strategies used by the teacher in teaching speaking, interviews were conducted. In addition, interviews are based on three components of perception; they are cognitive, conative, and affective components (Walgito, 2010).

\subsubsection{Cognitive Component}

This component relates to the knowledge, beliefs, or thoughts of participants about the strategies used by the teacher in teaching speaking. From the interview data, the six participants had positive perceptions of the strategies used by the teacher in teaching speaking. In terms of knowledge, participants already know what strategy is. For example participant 1 representing the other participants said:

"Strategy is some type of activities that are done in the class to improve the students' understanding of the material given by the teachers." (Participant 1)

From the interview above, participant 1 agreed that the strategy used by the teacher greatly facilitates learning English, especially in speaking skills. Basically the teacher has indeed introduced what teaching strategies and strategies they will use to students as a means to help them learn to speak in class. Students are very open about the use of these strategies so that they give positive thoughts related to the strategies used by the teacher in teaching speaking. For instance, the participant 2, 3 and 4 said:

"The strategies used to teach speaking in Desa Bahasa Sragen are interesting." (Participant 2)

"Studying English here is extremely enjoyable". (Participant 3)

"These strategies are very helpful for the English learners, especially the one who learn to speak English." (Participant 4)

Based on the interview above, participant 2 argues that the strategy used by the teacher is an interesting application to make it easier for them to learn to 
speak in class. Meanwhile, participant 3 thought that the teacher's strategy was fun. Then, participant 4 thought that the strategy used by the teacher was good and suitable to facilitate speaking learning in the classroom.

In addition, as all the participants had experience with the strategies the teacher used to teach speaking, their beliefs about those strategies began to emerge. All participants showed positive cognition regarding their beliefs about the strategies used by the teacher to teach speaking in the classroom. For example, participants 2, 4 and 6 said:

"By learning English in Desa Bahasa Sragen, I could learn to speak English easier." (Participant 2)

"To be honest, learning English using this type of strategy is new to me, and it has really helped me practice speaking my English. I can learn pronunciation and also acquire new vocabulary." (Participant 3)

"For me, learning English in Desa Bahasa Sragen makes it easy for me when I learn to speak English both in class and outside of class hours. I can learn how to pronounce English words and vocabulary too." (Participant 4)

Although learning English using strategies in Desa Bahasa Sragen was still new to the participants, it proved to be beneficial for the participants' language learning, especially in speaking. All participants believe that these strategies can help them in learning several aspects of speaking such as pronunciation, intonation, fluency, comprehension, grammar, new vocabulary and even English expressions.

\subsubsection{Conative Component}

In the conative component, perception refers to the actions or activities of the participants. Based on the data collected from the interviews, the six participants had positive perceptions of the strategies used by the teacher to teach speaking. They explain some of the activities they do to improve their speaking skills with the help of strategies in class. For example participant 4 represents participants 1 and 3 say:

"Our teacher told us to use the hands when memorizing something because research proves that it helps the students to memorize something faster when we also use our hands." (Participant 4)

Participant 4 mentioned that using his hands when memorizing something was effective in helping him improve his speaking skills. All students love to do that because it is fun. This is also supported by the fact that students look very active when doing activities in class.

Apart from that, participant 5 who represented participant 2 mentioned other activities he did in Desa Bahasa Sragen and the following was the interview transcript.

"The teacher helps us memorizing vocabularies by singing. It made us, especially me, easier to memorize new vocabularies." (Participant 5) 
From the interview above, it can be seen that the strategy used by the teacher in Desa bahsa Sragen is quite effective. In addition, they can easily understand the speaking learning material provided by the teacher.

In addition, this special component is also focused on revealing the possibility or willingness of students to learn English outside the classroom. Several participants shared their experiences about using this strategy to make it easier for them to learn to speak in their spare time at home. For example participants 2, 3 and 6 said:

"After tired playing games at home, I study English again at home the same way as my teacher taught me in the class". (Participant 2)

"When I have nothing to do, I will practice my English with my parents or my siblings at home". (Participant 3)

"I can teach English to my sister using the same strategies used in Desa Bahasa Sragen". (Participant 6)

From the above interview, participants 2, 3 and 6 representing other participants stated that they were very happy to learn English at home by learning in Desa Bahasa Sragen. Participant 6 even stated that he could teach English to his younger sibling.

\subsubsection{Affective Component}

The affective component refers to a feeling or emotional dimension that is not mediated by thoughts. Based on the data collected from the interviews, the six participants effectively had positive perceptions of the strategies used by the teacher to teach speaking. For example, on behalf of the other participants, participants 1 and 3 said:

"I like and enjoy studying here because it makes learning to speak in class more relaxed, and learning time feels fast." (Participant 1)

"Learning English in Desa Bahasa Sragen does not make me sleepy. The strategy used has brought me a new learning atmosphere, and I love studying here." (Participant 3)

From the interview, the participants admitted that they were happy to study in Desa Bahasa Sragen because studying there provided a pleasant learning atmosphere that cannot be obtained when learning to speak English using only books. The strategies used by the teacher can relieve their boredom so that the learning process to speak becomes more enjoyable and makes them feel that the learning time is very short.

In addition, Desa Bahasa Sragen's teacher uses several strategies in teaching speaking. All participants mentioned that they have a favorite strategy so participant 1 and participant 5 mentioned their favorite strategy while studying in the Sragen Language Village. Below is a transcript of the interview displayed with participants 1 and 5 .

"I adore the discussion strategy." (Participant 1)

"My favorite strategy in Desa Bahasa Sragen is the picture Describing." (Participant 5) 
In the discussion, students are asked to discuss several topics given by the teacher. They do it in pairs. Meanwhile, in describing the picture, the teacher will show the picture to the student, then the teacher will give an example in describing it then ask the student to repeat what she said. Furthermore, different from the other participants, participant 3 stated that he really liked all the strategies used in Desa Bahasa Sragen to learn English, especially speaking. The following transcripts of the interview with participant 3 are presented below.

"All of the strategies that are used by the teacher to teach speaking in Desa Bahasa Sragen attracted me to learn to speak." (Participant 3)

As cited in the transcript above, participant 3 agreed that all the strategies the teacher used to teach speaking were very interesting. They are very appropriate to be used to support students in learning to speak.

\section{Discussion}

There is a main scope of findings discussed, namely students' perceptions of the strategies used by teachers to teach English in Desa Bahasa Sragen. The reveal from the in-depth interviews with six students showed that all of them had positive perceptions. Their positive perceptions are built from their cognitive, conative, and affective evaluations of the strategies used by teachers in Desa Bahasa Sragen.

In terms of the cognitive component, students gave positive opinions on the strategies used by the teachers in Desa Bahasa Sragen which were considered interesting, good and suitable to be used to facilitate their language learning in the classroom. Therefore, this strategy plays an important role in motivating students, especially in learning to speak. The strategies used by the teacher can motivate students to practice more, because they have the willingness to do what has been taught in the classroom at home. Strategies help students with their pronunciation, vocabulary, expressions and intonation. Therefore, the strategy used by the teacher can help students overcome speaking problems such as pronunciation, intonation, expression, grammar, fluency and vocabulary.

In addition, the strategies used by the teachers in Desa Bahasa Sragen can also help students to prevent monotonous speaking learning. Desa Bahasa Sragen offers students various ways to learn to speak such as discussion and picture narrative. The strategy forces them to speak English actively so that they can master vocabulary and strive to speak fluently.

Students' positive perceptions of the strategies used by the teacher in teaching speaking in Desa Bahasa Sragen were also proven by their willingness to practice English outside the classroom. As it is known that to improve students' speaking ability, it is not enough for students to rely solely on speaking learning in Desa Bahasa Sragen. The allocation of learning time to speak in class is limited, so students need to practice speaking outside class hours. By using the strategies given to them, students can use their spare time to practice speaking English. Students not only practice alone but can also 
invite friends or relatives to practice together so that the teaching and learning process becomes more enjoyable.

Furthermore, from an affective perspective, students expressed their positive perceptions by expressing their feelings about the strategies used by the teacher in teaching speaking in the Desa Bahasa Sragen. From these findings, all the participants admitted that they were happy to study in Desa Bahasa Sragen because it could relieve their boredom while studying in class. The various strategies given by the teacher brought fun learning to the students; the positive feelings of the students were then supported by several strategies used by the teacher in teaching speaking in Desa Bahasa Sragen which they called their favorite strategy.

In addition, students' positive perceptions of the strategies used by the teacher in teaching speaking in Desa Bahasa Sragen were influenced by new experiences given by the teacher in Desa Bahasa Sragen. Various new ways of learning to speak through this strategy lead to new dimensions and bring a new atmosphere for students when learning to speak in class.

\section{Conclusion}

The results of this study indicate a positive perception of the strategies used by the teacher in teaching speaking in Desa Bahasa Sragen. From the cognitive aspect, all participants gave positive thoughts and believed that the strategies used by the teacher in teaching speaking in Desa Bahasa Sragen brought many benefits to support students' learning to speak English both inside and outside the classroom. According to the participants 'opinion, the strategies used by the teacher in teaching speaking in Desa Bahasa Sragen provide excellent learning opportunities, especially in overcoming students' speaking problems such as pronunciation, intonation, comprehension, grammar as well as vocabulary and expressions. Regarding the conative aspect, the participants conveyed their positive activities regarding the strategies used by the teacher in teaching speaking in Desa Bahasa Sragen which helps them to improve their speaking skills so that they are also willing to use the strategies that have been taught outside school for hours to spend their spare time. Apart from that, the participants also expressed their positive feelings towards the strategies used by the teacher in teaching speaking in Desa Bahasa Sragen in learning to speak English. All students are happy with the strategy used by the teacher to teach speaking in Desa Bahasa Sragen because it makes learning more fun than just using books. Several factors that underlie and influence their positive perceptions are also discovered and expanded by the presence of new experiences in learning to speak.

\section{References}

Ahmadi, A. (2013). Psikologi Belajar. Jakarta: Rineka Cipta.

Ary, J. et al. (2002). Introduction To Research In Education. Belmont: Wadsworth

Cole. R. W. (2008). Educating Everybody's Children: Diverse Teaching Strategies for Diverse Students, Revised and Expanded 2nd ed. Virginia: Association for Supervision and Curriculum Development (ASCD). 
Creswell, J. W. (2012). Educational research: Planning, conducting, and evaluating quantitative and qualitative research. Boston: Pearson Education, Inc.

Gibson, J.L., Ivancevich, J. M., and Donally, J.H. (1996). Teacher efficcacy: A construct validation. Journal of Education Psycology, 76, 569-582.

Isjoni. (2009). Pembelajaran Kooperatif: Meningkatkan Kecerdasan Komunikasi Antar Peserta Didik. Yogyakarta: Pustaka Belajar.

Kotler, P. (2000). Analysis, Planning, Implementation and Control. New Jersey: Prentice Hall International, Inc.

Nichols, R. (2007). Thomas Reid's Theory of Perception. Oxford: Oxford University Press.

Hasria, R. S., Fathu, R., \& Andjarwati, S. (2018). Improving the students' speaking ability through Silent Way Method at SU Negeri 12 Makassar. Journal Ilmu Budaya. 6, 303-312. https://doi.org/10.34050/jib.v6i2.4289

Junaidi, J., Hamuddin, B., Julita, K., Rahman, F., Rianita, D., \& Derin, T. (2020). Artificial Intelligence in EFL Context: Rising Students' Speaking Performance with Lyra Virtual Assistance. International Journal of Advanced Science and Technology, 29(5), 6735 -6741.

Reiser, R. A., \& Dick, W. (1996) Teacher Planning and Instructional Design: A New Perspective. Paper presented at the meeting of the association for educational communications and technology, Indianapolis.

Robbins, J. (1996). Between "Hello" and "See you later": Development of strategies for nterpersonal communication in English by Japanese EFL students. Published Dissertation. Michigan Universtity Press: Ann Arbor.

Robbins, S. (2002). Prinsip-Prinsip Perilaku Organisasi (Edisi Kelima). Jakarta: Erlangga.

Robbins, S. (2013). Organizational Behavior (15th Edition). Prentice Hall.

Ruslan, R. (2010). Manajemen Public Relation dan Media Komunikasi. Jakarta: Rajawali Pers.

Walgito, B. (2010). Pengantar Psikologi Umum. Yogyakarta: Andi Ofset. 